duserer Rockefeller Foundations utvikling. Dette er basert på sekundærlitteratur, og forfatteren kunne med stor fordel ha utvidet litteraturgrunnlaget. Etter et kapittel om «Biokemi på svenska» følger det som for meg representerer høydepunktet, «Molekylärbiologi före molekylärbiologin, RF og KI 1935-1939». Instituttets historie under andre verdenskrig og en diskusjon av det medisinske nobelinstituttet, som ble tilgodesett med støtte fra Rockefeller Foundation etter krigen, avslutter boken.

For lesere som ønsker en generell introduksjon til Rockefeller Foundations rolle i naturvitenskapenes og medisinens historie vil Robert Kohlers Partners in science (1), som Ljungströms fremstilling av stiftelsens historie bygger på, være et mer hensiktsmessig førstevalg. Boken er likevel interessant både om Karolinska Institutets historie og om fremveksten av en klynge internasjonalt anerkjente forskningsgrupper innen de aktuelle fagområdene i den europeiske utkant.

\section{Erik Ingebrigtsen}

Det medisinske fakultet

Norges teknisk-naturvitenskapelige universitet

Litteratur

1. Kohler R. Partners in science: foundations and natural scientists, 1900-1945. Chicago, IL: Chicago University Press, 1991

\section{Interessant, men lite nyttig}

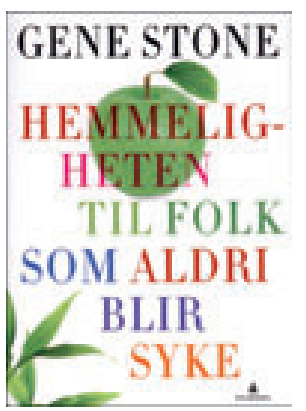

Gene Stone

Hemmeligheten til folk som aldri blir syke

232 s, ill. Oslo: Gyldendal, 2011. Pris NOK 349

ISBN 978-82-05-40967-5

Boken er dedikert alle dem som jobber for et helsevesen som er like opptatt av å forebygge som å helbrede sykdom. Leserkretsen er trolig mer «hvermandsen» enn fagfolk og helsepersonell. Den amerikanske forfatterens intensjon synes å være å gi innblikk i mer eller mindre særegne hemmeligheter for å bevare helse og å unngå sykdom.

Boken er innbundet, trykt i god kvalitet, har figurer og faktabokser som sammen med relativt kortfattede og oversiktlige kapitler gjør den lettlest. Oversiktlig stikkordsregister gjør det mulig å finne frem til avgrensede elementer i de enkelte helsehemmelighetene som omtales.

I innledningen forsøker forfatteren å rettferdiggjøre det valget som er gjort med hensyn til hva som har kommet med. Hoveddelen består av 25 helsehemmeligheter som målbæres gjennom enkeltpersoner som har levd sine liv i sterk tro på at akkurat deres levemåte har bidratt til at de har bevart helsen og er blitt gamle uten å ha vært plaget med sykdom. De utvalgte helsehemmelighetene faller i hovedsak i tre hovedkategorier: kosthold, aktivitet og livsstil.

Kalorireduksjon og plantebasert kosthold er rimelig omforent ut fra allmenn medisinsk kunnskap. Systematisk bruk av urtemedisin, C-vitamin, hvitløk, ølgjær, probiotika og et pH-balansert kosthold er også gjenkjennelig innenfor norsk standard av alternativ kosttilrettelegging. Mer sært er nok avgiftningskosthold, det å spise skitt, og at kyllingsuppe er en helt vesentlig bestanddel av kostholdet.

Treningsterapi, løping, vektløfting, stretching og yoga er også allmenngyldige helsehemmeligheter som det heller ikke er kontroversielt å slutte seg til som gode helseråd. På samme måte er det å ha en positiv innstilling, fri religionsutøvelse, frihet fra stress samt en daglig middagslur slett ikke å forakte som interessante helsefremmende tiltak. Helseråd som å sørge for gode gener eller ha tilhørighet til jordens blå soner, er nok vanskeligere å etterleve.

På mange måter presenterer boken et variert sett av livsråd som den interesserte leser nok vil finne underholdende å lese om. Den praktiske medisinske nytten av en slik bok vil vel imidlertid være begrenset. Forfatteren uttaler seg også temmelig skråsikkert om nærmest enhver påstand, og innholdet preges av løsaktig omgang med forskning og evidensbegrepet. Svært mange helseråd presenteres som vitenskapelig bevist uten at det noe sted i teksten er ført opp en eneste referanse.

Personlig opplevde jeg boken som interessant, men dessverre ikke særlig nyttig for meg som forsker eller lege. I en norsk medisinsk setting vil jeg hevde at flere av bøkene om kjerringråd og alternativ medisin i Norge vil tilføre mer nyttig kunnskap enn denne boken.

\section{Arne Johan Norheim}

Nasjonalt forskningssenter innen komplementær og alternativ medisin Universitetet i Tromsø

\section{Välkommen, infektionerna vänter på dig}

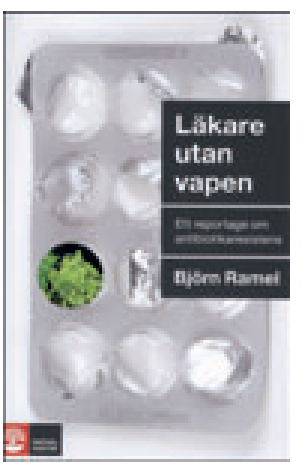

Björn Ramel

\section{Läkare utan vapen}

Ett reportage om antibiotikaresistens. $280 \mathrm{~s}$, tab, ill. Stockholm: Natur och Kultur, 2011.

Pris SEK 180

ISBN 978-91-27-12022-8

Overskriften er fra ett av kapitlene i boken til Bjørn Ramel, svensk lege, journalist og lederskribent på Sydsvenskan, en av Sveriges store aviser. Gjennom 20 kapitler belyser han den store utfordringen som moderne helsevesen nå står overfor: Mikrobene er i ferd med å avvæpne oss, antibiotika virker ikke lenger.

Forfatteren går til verks med stor grundighet. Mikrobenes store tilpasningsevne belyses på en enkel og oversiktlig måte. De er evolusjonens mestere. Han understreker betydningen av respekt. Det store flertallet er venner - og vi må ikke gjøre dem til fiender. Etter å ha blitt bombardert med antibiotika i 70 år slår mikrobene nå tilbake med en økende flokk av «resistensbomber»: MRSA, ESBL, VRE,VRSA, AmpC, KPC1, MBL, PRP, MDV1.

I boken belyses med velvalgte eksempler hvordan dette har skjedd, og med like velvalgte eksempler hvordan advarslene er blitt ignorert. Det har ikke manglet på møter og fine deklarasjoner, men det har manglet politisk vilje til å gjennomføre disse. WHO høster liten heder, det samme gjør den farmasøytiske industrien, EU og overvåkingsorganet (European Centre for Disease Prevention and Control (ECDC), som er lokalisert i en tidligere blindeskole utenfor Stockholm. Han sammenlikner resistensutvikling med klimaendringene som begge er menneskeskapte og kan hindres eller forsinkes. I dagens situasjon vil det reddes langt flere liv om man kunne hindre utvikling og spredning av antibiotikaresistens enn å redde regnskog. Det tar mye lengre tid å få senket resistensnivået enn det vi hittil har trodd.

I Norden har vi sluppet relativt lett unna. Alle nordiske land har selvsagt alle typer av multiresistente bakterier, men problemene er mindre hos oss - enn så lenge. Forfatteren redegjør for forholdene i mange land, som Kina, India, Kenya og land i Sør-Europa. Hans 